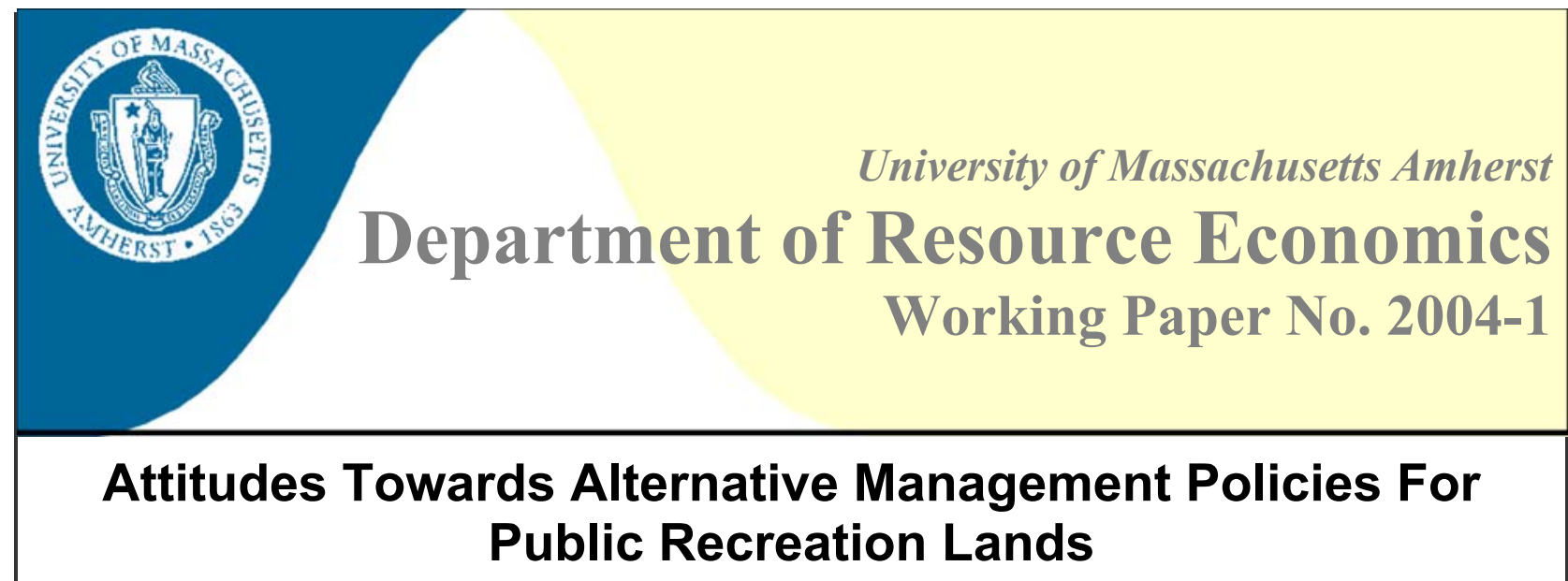

\author{
Mihail Samnaliev ${ }^{1}$, Thomas Stevens ${ }^{2}$, and Thomas More ${ }^{3}$
}

\begin{abstract}
:
Public recreation land management agencies have been searching for ways to increase revenue. User fees as implemented by the Fee Demonstration Program have received the most attention. Corporate sponsorships and private donations have also been implemented and other options, such as partial privatization, closure of some areas, and different forms of public-private partnerships have been debated. The present paper reports results from a 2002 mail survey of randomly selected Idaho and New Hampshire households, designed to elicit public attitudes about a wide variety of management policies for public (federal/state) recreation lands. The most socially acceptable forms for raising revenue were donation boxes $(61.1 \%)$, corporate sponsorships for visitor centers $(61.8 \%)$ and education facilities $(61.1 \%)$, and adopt-a-site contracts $(81.0 \%)$. Both increased taxes and user fees faced greater opposition (about $49 \%$ of respondents) than support (39\%). In addition, user fees have resulted in (reported) changes in behavior among a quarter of the respondents, and may have stronger negative impact on lowincome households and on the users of public recreation lands.

This study is relevant to the current debate in Congress about the future of the Fee Demonstration Program. Our findings can also be used by policy makers interested in raising revenue through socially acceptable management policies. Our results suggest that donations, adopt-a-site and corporate sponsorships (for selected areas) should be used to raise additional revenues, and if additional funding is needed, policy makers may be justified to advocate for increased taxation rather than fees.
\end{abstract}

Keywords: user fees, corporate sponsorships, public recreation lands

JEL Classification: I38, Q28

${ }^{1}$ Mihail Samnaliev, Department of Resource Economics

80 Campus Center Way, University of Massachusetts, Amherst, MA 01003

E: samnaliev@,resecon.umass.edu P: 413-253-9072 F: 413-545-5853

${ }^{2}$ Thomas Stevens, Department of Resource Economics

80 Campus Center Way, University of Massachusetts, Amherst, MA 01003

E: tstevens@,resecon.umass.edu P: 413-545-5714 F: 413-545-5853

${ }^{3}$ Thomas More, USDA, Forest Service, Northeastern Research Station

P.O. Box 968, Burlington, VT 05402

E: tmore@fs.fed.us 


\title{
Attitudes Towards Alternative Management Policies For Public Recreation Lands
}

\author{
Mihail Samnaliev* \\ Thomas Stevens ${ }^{* *}$ \\ Thomas More ${ }^{* * *}$
}

* Corresponding author

Department of Resource Economics

University of Massachusetts

80 Campus Way,

Amherst, MA 01003

fax:+1-413-545-5853 e-mail: samnaliev@resecon.umass.edu

${ }^{* *}$ Department of Resource Economics

University of Massachusetts

80 Campus Way,

Amherst, MA 01003

${ }^{* * *}$ USDA, Forest Service, Northeastern

Research Station, P.O. Box 968.

Burlington, VT 05402 


\section{Introduction}

The social impact of user fees associated with the current Fee Demonstration Program (FDP) for public outdoor recreation ${ }^{1}$ has been controversial. Supporters argue that fees (a) raise revenues, (b) ensure efficient management and (c) increase fairness to non-users of public recreation lands. Opponents claim that fees are inconsistent with the traditional practice of open and equal access to public lands, and result in reduced visitation, exclusion of low-income families and displacement of use to other areas (Richer and Christensen 1999; More and Stevens 2000;

Bowker et al. 1999; Schneider and Budruk 1999).

Alternative management practices (MP) to raise revenues have been debated but their social acceptance relative to the FDP has not been studied in detail. For example, donation boxes and corporate sponsorships are already being used at some sites to supplement government funding. These two policies have the potential to increase revenue while maintaining open public access to recreation lands. Partial privatization and private-public partnerships, which have only been debated so far, may increase revenue, but lead to reduced visitation by low-income people. Taxes can ensure equal access, but may result in underfunding and inefficient resource allocation. Finally, closure of some recreation lands, although an extreme measure, is a way to cut overall expenditures. Given the variety of management options, a comparative analysis of public attitudes about each could be helpful to policy makers whose ultimate goal is to increase revenue while retaining the egalitarian function of public recreation lands.

In previous research attitudes about public land management policies have typically been elicited without considering a broad range of alternatives. As the focus of analysis has mostly

\footnotetext{
${ }^{1}$ The Fee Demonstration Program (FDP) has been experimentally implemented for some public lands and allows the Forest Service, the Bureau of Land Management and the U.S. Fish and Wildlife Service to impose access fees for public use of these lands. The purpose of the FDP is to test the appropriateness of entrance fees as a mechanism to raise additional money to maintain public natural resources and recreation sites.
} 
been on attitudes about user fees, the input of non-visitors of public recreation lands has largely been ignored. Most studies have not directly compared (by using the same sample of respondents) support for user fees relative to traditional funding through taxes, and as far as we are aware, apart from corporate sponsorships, public attitudes for other alternatives to fees have not been elicited. The focus of this paper is on public opinions for alternative forms of management of public lands relative to user fees and taxation.

\section{Previous research}

Studies that have sampled visitors at specific recreation areas have often reported public support for user fees. For example, Vogt and Williams (1999) sampled campers in the Eldorado National Forest and the Lake Tahoe Basin Management Unit and report general support for wilderness use fees with strongest support for restoration of damaged sites, litter removal and information provision. Williams et al. (1999) also concluded that the general attitude towards fees was positive and respondents seemed more likely to accept paying for an experience or service and less likely to favor access or transaction fees. Strongest opposition was expressed against payment for swimming (38.1\%), wilderness day trips (35\%), parking fees $(27.1 \%)$, and mountain climbing (27.6\%) but RV camping, visiting historic sites, water sports and park entrance fees were opposed by only $2.4 \%$ to $19 \%$ of visitors. Bowker et al. (1999) asked respondents whether they supported user fees, taxes or a combination of both for ten types of recreation sites. They report that $95 \%$ of respondents supported either a fee or a combination of fees and taxes. Visitor centers, trails, rest rooms, parking areas and historic sites received greater tax support, and campgrounds, special exhibits and boat ramps received greater support for user fees. A recent report by the National Park Service (Solop et al. 2003) studied public opinions of more than 
3000 households nationwide of both visitors and non-visitors. Major barriers to visitation were found to be lack of time and distance, rather than user fees. Specifically, when non-visitors were asked why they had not visited national park system units, their most frequent response was that they were too busy (38\%), it was too far to travel (37\%), or because of lack of information $(15 \%)$. Seven percent reported that it was because of entrance fees, and $11 \%$ because the overall costs were too high. Still, $27 \%$ of the respondents thought that entrance fees were too high. This percentage was significantly greater among low-income groups, reaching $34 \%$ among respondents whose annual income was less than $\$ 20,000 /$ year.

Opposition to user fees has focused mainly on the issues of equity, reduced visitation and displacement. More (1999) argues that public lands must serve public objectives that do not have to coincide with profit maximization. More argued that the critical question is "How well is the public function being served?" as opposed to "How well is the agency managing the public land doing?" Richer and Christensen (1999) interviewed visitors of the Desolation Wilderness, and concluded that a $\$ 5$ fee would generate the most revenue, but would also reduce visitation by $52 \%$ compared with the current situation of free access. On the other hand, a $\$ 2$ fee would lead to a $30 \%$ reduction in revenue, as compared to a fee of $\$ 5$ and would only decrease the number of visitors by $17 \%$. The authors concluded that fee imposition would impend one of the main objectives of public lands: open access. More and Stevens (2000) found that even though user fees were widely accepted by the public, they may have significant impact on low-income families. They estimated that a $\$ 5$ daily fee for use of public lands would impact about $49 \%$ of low-income people. Giraud (2001) found that a $\$ 1$ and a $\$ 5$ user fee would reduce visitation by almost the same degree and concluded that respondents opposed the idea of fees, rather than the fee amount. They also found that many respondents who stated that they would pay fees were 
unwilling to support imposition of user fees because of concerns about young families' ability to pay. Schneider and Budruk (1999) found that displacement as a response to entrance fees is also an issue. One third of respondents in their study reported change in visitation as a result of the FDP and displacement occurred among 53.3\%. Consistent with this result, Bowker et al. (1999) reported that local visitors showed greater resistance to fees as compared to out-of area respondents. In summary, the existing literature on the FDP suggests that user fees, although not supported by the majority of the people, face greater support than opposition. However, fees have often been perceived as unfair and may have resulted in exclusion of low-income users and displacement of local residents.

Previous research on attitudes about corporate sponsorships has been scarce. Most of the attention has focused on how to attract potential sponsors and raise revenue while public attitudes have been considered as less important. Among the few studies, Mowen and Graefe (2002) and Mowen and Frankberger (2000) elicited public attitudes towards two types of corporate sponsorships for municipal facilities and programs including, (a) promotional activities (such as title sponsorship, location of sponsor identification and type of promotional activities) and, (b) contractual conditions (such as number of corporate sponsors, length of sponsorship contracts, etc.). This study reported that a majority of their sample expressed support for sponsorships (53\%), and greatest support for sponsorships with local companies, monetary sponsorships, and sponsorships of free programs. Support for sponsorships also differed by type of location; facility scoreboards, golf clubhouses, ballfield fences and recreation centers was perceived as the most appropriate locations, while historic sites and trails were perceived as the least appropriate locations for sponsorship identification. The authors called for municipal park 
agencies to 'remain conservative' regarding sponsorships, pointing to the significant portion of respondents who were neutral (32\%) or opposed (15\%) to corporate sponsorships.

\section{Methods}

A mail survey was used to elicit attitudes towards a wide variety of alternative MP for public recreation lands. The survey, pretested with a pilot survey 4 months earlier, was mailed in October of 2002 to a total of 2600 households in New Hampshire and Idaho. These two states have similar demographics and political orientation, but differ significantly in the percentage of land that is public. To obtain representative samples for each state, two-stage cluster sampling was applied. Urban and rural residential areas were first randomly selected and within each a random sample size relative to the population of the respective area was obtained. We followed the four-step procedure outlined by Dillman (2001) which yielded a response rate of $33 \%$ and a total of 806 observations.

On the questionnaire we first sought to establish a broad framework about the socially desired outcome of management policies for public lands. Respondents were told that Congress was debating several bills about the FDP, and were asked to rank the most important issues (among several options) that Congress should consider when evaluating the FDP (See Table 2) ${ }^{2}$. Second, attitudes for specific management practices (MP) were elicited. Respondents were provided with information about the FDP and asked for their opinion about user fees for access to public lands. Respondents' actual response to user fees was also elicited by asking if and how

\footnotetext{
${ }^{2}$ Two opposing types of management policies were considered. The first included measures that could increase efficiency: raising fees, getting agencies to be more 'business-like' and making areas more responsive to consumer demand. The second type included policies aimed at keeping lands affordable to low income users and at encouraging family oriented activities (See Table 1)
} 
user fees had affected their visitation. Then, a set of questions asked for respondents' attitudes towards user fees and alternative management practices (See Table 4).

\section{Sample description}

Basic socioeconomic characteristics of respondents are summarized in Table 1. Respondents had a median income of $\$ 52,000 /$ year, median age of 55 years and most of them had some college education. Although a representative sampling design was used, respondents had higher education and age as compared to the population statistics for Idaho and New Hampshire (See footnote in Table 1). Although this pattern is typical of general population mail surveys, our results cannot be extrapolated to the population as a whole. Of some interest is that Idaho respondents had a higher level of education and visited public lands twice as often as compared to New Hampshire respondents, suggesting the possibility of a more outdoor oriented lifestyle. However, most differences between states were statistically non-significant, so the next section presents the pooled data for both states. This is followed by a regression analysis of public attitudes, controlling for state, frequency of visitation and socioeconomic characteristics.

\section{Public opinions of the pooled sample}

Public opinions about the most important considerations that policy makers should take into account in evaluating the FDP were elicited through the following question:

"Congress is currently debating several bills about the fee demonstration program. Some want to make the program permanent and apply it to more areas. Others would eliminate it altogether. In evaluating this program, which of the following considerations do you think should be most important?" (List options as in Table 2) 
Respondents could check multiple options, and were asked to select which was the most important (Table 2, Column 3). About 30\% of the respondents thought that the most important consideration was to keep public lands affordable for low-income families and about $25 \%$ thought that the principle concern should be to keep prices low to encourage family centered activities. Combining these two categories yields a majority (55.7\%) of the respondents. Alternatively, $11 \%$ believed that prices should be raised so that recreation areas pay for themselves, 5.6\% believed that public agencies should be more "business like", and 7.5\% believed that recreation lands should be more responsive to consumer demand. The latter three categories constitute about a quarter of respondents. These results suggest that, in principal, the general public prefers to keep public lands affordable and non-exclusive. At the same time a majority of respondents opposed the idea of reduced maintenance to keep public recreation areas free, as well as closing down areas that cost the most to maintain (See Table 4). These results indicate that management policies will be socially acceptable if they are designed to serve the dual objectives of (i) raising more revenues to maintain the current number of recreation areas but, (ii) ensuring non exclusion of low-income groups or families ${ }^{3}$.

When asked if they had changed their behavior (in the past 12 months) in response to the FDP, $26 \%$ of the respondents stated that they had avoided going to recreation areas because of entrance fees, $25.2 \%$ reported that they were not affected by user fees and $39 \%$ responded that they had not visited public lands in the past 12 months (see Table 3). Thus, a conservative estimate is that at least one in four respondents had actually been affected by user fees.

Since, with few exceptions, most of the proposed alternatives to user fees have not been implemented, we could not elicit information about actual public response to each MP as was

\footnotetext{
${ }^{3}$ In this regard, user fees set by market demand and supply have been argued to be mutually exclusive in achieving such dual objectives (For example, see Richer and Christensen 1999)
} 
done for user fees. The following analysis is thus limited to public support and opposition for proposed, rather than implemented management policies, assuming that opposition implies some form of disutility. Our analysis was derived from questions that used identical format to elicit public support for each MP. The following question was asked:

"If the U.S. Forest Service does not have enough money or staff to adequately maintain its outdoor recreation sites, how much would you support or oppose the following options" (List alternative MP as in Table 4)

In addition, we assessed public support for corporate sponsorship for different groups of activities and recreation sites using the following question:

"In your view, how appropriate is it for each of the following facilities in National Forests to receive and be identified as having corporate sponsorship?" (List options as in Table 5)

Frequency distribution of public support for each management policy is shown in Table 4, and for corporate sponsorship in Table 5. Among the MP-s listed in Table 4, a majority of respondents supported the 'adopt-a-site' option followed by 'donation boxes'. A majority of respondents opposed 'sell some of the areas', 'close areas that cost the most to maintain', and 'keep all areas free but reduce maintenance'. Support or opposition for the remaining MP-s did not exceed $50 \%$. User fees and 'increased taxation' were equally opposed by slightly less than half of the respondents, as was 'Contract with private companies to manage sites'. Among the options for corporate sponsorships, most respondents supported corporate sponsorship of visitor 
centers $(61.8 \%)$ and education facilities $(61.1 \%)^{4}$. The remaining options were not supported or opposed by a majority: corporate sponsorship of campgrounds was supported by $45.9 \%$, and opposed by $35.9 \%$ of respondents and sponsorships for the remaining options received greater opposition than support. The proportion of uncertain responses varied widely, from $9.1 \%$ to $22.5 \%$.

\section{Determinants of support}

Logit models were used to examine the effects of individual socio-economic factors that might determine support for each MP. Establishing such associations shows which sub-groups of the population may be most adversely affected by each policy measure ${ }^{5}$. The independent variables of primary interest were (i) frequency of visitation and, (ii) income, where greater opposition by low-income respondents would indicate that they would be more affected by the respective MP.

One advantage of logit models is that they provide information about the likelihood of public support for each MP as a function of socioeconomic variables. This allows us to estimate the relative magnitude of impact of each significant variable in the model. Binary as well as ordered logit models (where the Not Sure category was included in the model as an ordered category) were fit for each alternative MP. Since the two types of models produced similar estimates and statistical significance, only results of the binary models are shown (See Table 6a and $6 b)$.

Variables included in the logit models are summarized in Table 1. In terms of specific hypotheses, we expected positive associations between income and any MP that may increase the

\footnotetext{
${ }^{4}$ Comparison of support among the alternatives listed in Table 4 and in Table 5 should be done with caution, since the question was phrased differently in the two cases.

${ }^{5} \mathrm{We}$ assume that opposition reflects some form of disutility due to negative impact of the MP that has been considered.
} 
cost of visitation, because low-income respondents would be expected to oppose such MP-s to a greater extent than high-income respondents. On the other hand low-income respondents, especially low-income visitors of public lands would be expected to prefer financing public facilities via taxes. Frequent visitors can be expected to be less likely to support MP that may increase the cost of visitation, and more likely to support taxation. In addition, it may be useful to know whether visitors would favor increased maintenance and facilities in recreation areas, or would oppose MP that incur "intervention into the wilderness". Respondents' age, gender, education, and geographic location (state) were also controlled for. Finally, individual attitudes about public lands were included in the models. People who believe in the egalitarian function of public recreation lands (those selecting the most important concern to be 2 or 7 , as listed in Table 2) should show greater support for taxation and donation boxes regardless of income, frequency of visitation, age, etc ${ }^{6}$.

Regression results are presented in Table $6 a$ and $6 b^{7}$. Several consistent patterns emerge from the estimation. First, the most powerful explanatory variables were 'visits' and 'attitudes'. 'Visits' had a negative sign for all MP, except taxation and support for reduced maintenance, where it had a positive sign. This suggests that visitors of public lands oppose MP involving user fees or the private sector, but support the traditional practice of public finance via taxation. Visitors were also more supportive of a MP to reduce maintenance, but keep all areas free as

\footnotetext{
${ }^{6}$ Functional form was examined for education, income and age. The possibility that these variables should be entered with a quadratic or logarithmic term was evaluated graphically and through goodness of fit, and significance of the variable. The linear forms turned out to provide the best fit. Interaction between 'visits' and 'income' and 'visits' and 'state' were insignificant. Goodness of fit of the models was assessed using the standard likelihood ratio test. Residual analysis was conducted by examining the change in $\chi^{2}$, deviance, and estimated coefficients. In order to reduce multicollinearity, (age with visits and income with education) age, income and visits were coded in categories as shown in Table 1.

${ }^{7}$ Since the models on support for the 'adopt-a-site', 'sell some areas' and 'close areas that cost most to maintain' had small number of observations for one of the two outcomes of the dependant variable, they may not adequately capture the effect of the independent variables.
} 
compared to non-visitors. The second result is the significant effect of attitudes. As expected, this variable was positively associated with MP that would promote equal access (donation boxes, 'reduce maintenance but keep areas free' and 'increased taxation') and negatively associated with MP that may exclude low-income subgroups (user fees). Attitudes were also positively related with corporate sponsorships for visitor centers, education facilities, and nationally significant trails. Finally, high-income was positively associated with support for user fees, 'contract with private companies', and corporate sponsorships for some areas. However, income was not always a significant determinant of opinions. The expectation that low-income respondents would be more supportive of increased taxation and less supportive of 'sell some of the areas' was not supported by the data. Conversion of the coefficient estimates into odds ratios shows the estimated magnitude of the effect of each variable on the likelihood of support for the respective MP. For example, all else equal, regular and occasional visitors were estimated to be, on average, two times (0.4-0.6) less likely to support user fees as compared to occasional and non visitors, respectively and respondents with high or medium income, were 1.1 to 1.9 times more likely to support user fees as compared to respondents with medium or low income, respectively. Regular (occasional) visitors, on the other hand were 1.3 to 2.2 more likely to support reduced maintenance, and up to 1.8 times more likely to support increased taxation as compared to occasional visitors (non-visitors). Idaho residents were more likely to support "close areas that cost the most to maintain', 'increased taxation', and corporate sponsorships for scenic overlooks, nature walks, and nationally significant trails as compared to New Hampshire residents. Attitudes had the strongest effect: Respondents who believed that in principle public lands should be kept affordable were 1.2-3 times more likely to support donation boxes, up to 2.4 times more likely to support 'reduced maintenance', 1.9-3.9 times more likely to support 
increased taxation, and as much as 2.2 times more likely to support corporate sponsorships for visitor centers and education facilities, as compared to respondents who did not think that affordable access to public lands should be the most important concern. At the same time they were much less likely to support user fees, and 'close areas that cost the most to maintain'.

\section{Not Sure responses}

Studying the motivation underlying 'Not Sure' responses has been a focus of previous research involving surveys (For example Alberini et al. 2003; Wang 1997; Carson et al. 1998). In contingent valuation, this category has often been treated as missing data but recent evidence suggests that uncertain responses may be closer to 'No' responses. For example, Carson et al. (1998) showed that respondents who initially selected 'Not Sure' switched to 'No' after being 'forced' to make a decision. Many uncertain responses, however, may represent lack of knowledge, or lack of commitment to the question asked. They may also be viewed as the middle of three ordinal categories representing degree of support as respondents switch from 'No' to 'Not Sure' and from 'Not Sure' to 'Yes', an argument advocated by Wang (1997).

Insight into the motivation underlying uncertain responses could help improve survey techniques, increase the accuracy of analysis and ultimately provide more representative feedback on the policy measures that have been proposed. In this study, whenever the proportions of 'Yes' and 'No' responses were close and neither exceeded 50\%, a correct interpretation of uncertain responses is critical. Uncertain responses varied significantly across MP-s; support for contracting with private companies received $22.5 \%$ uncertain responses, while 'sell some of the areas' received only about $9 \%$ (See Table 4 ). The fraction of uncertain

\footnotetext{
${ }^{8}$ The proportional models that were fit for some of the MP assume Wang's approach. Details are available from the authors.
} 
responses for the remaining MP ranged from $12 \%$ to about $20 \%$. One explanation for the high number of 'Not Sure' answers is lack of familiarity with the potential impact of some of the proposed MP-s, which may make it difficult to give a definite opinion, as opposed to MP-s such as 'Sell some of the areas' for which the public seems to have well-formed opinions.

In an attempt to test whether 'Not Sure' responses could be classified as 'Yes', 'No' or missing, the distribution of responses was broken down by visits, education, age, income, and attitudes. Non-parametric tests were conducted to determine whether the distribution of 'Not Sure' responses by any of the above characteristics was the same as the distribution of 'No', 'Yes', or missing responses. There was no clear distinction between 'Not Sure' responses and either 'Yes' or 'No' responses. However, missing responses had a lower mean number of visits and education and greater mean age, as compared to the remaining three categories. These results suggest that it would be incorrect to recode uncertain responses as missing; excluding 'Not Sure' responses from the analysis would increase the relative percentage of support or opposition for each MP to above 50\%, even though actual support would likely be less than a majority. Logit models to explain 'Not Sure' responses as a function of the same regressors as in Table 1 were also developed ${ }^{9}$. The only consistently significant variable was frequency of visitation; regular (occasional) visitors were more certain in their responses as compared to occasional visitors (non-visitors). These results therefore imply that exclusion of 'Not Sure' responses, or reclassification into 'Yes' or 'No' is not warranted. A conservative approach which we follow throughout our analysis, is to retain the 'Not Sure' category, and base policy decisions on the percentage of support as shown in Tables 4 and 5.

\footnotetext{
${ }^{9}$ Non-parametric tests were conducted in SAS, using the Kruskal-Wallis test statistics to test for equality of distribution between the 'Not Sure' responses and 'Yes', 'No, or missing responses. In the logit models the dependent variable was coded as $0=$ 'Not Sure' and 1 otherwise. Since they are not central to our analysis, the results from these tests are not shown here.
} 


\section{Discussion}

If decision rules are based, at least in part, on public acceptance, it is useful to know the relative support for each MP as compared to tax appropriations which have been the traditional as well as the predominant source of revenue in public recreation lands.

\section{(i) User fees as a substitute to taxation}

Previous debate of the FDP has not clearly stated whether user fees will replace or supplement current tax appropriations. In either case, fees can be viewed as a substitute to taxation or to increased taxation, respectively. If policy makers set a goal to increase revenue above current levels, enforcement of the FDP could raise enough funds in order to avoid tax increases and vice versa, raising taxes to secure additional funding would be needed if the FDP were not implemented.

In general, the practice of income-progressive taxation spreads the burden of recreation land maintenance over all taxpayers and favors the users of public lands. Fees set by market demand are in effect income-regressive since they affect low-income users to a greater degree. Fees imply less governmental participation, greater efficiency, and favor non-users of public lands. Taxes will be paid by both the users and the non-users of public lands and may therefore be viewed as unfair by the latter. This argument, however, ignores existence values that nonusers may place on public lands ${ }^{10}$. In such case, non-users should also share the burden of public land management, although perhaps to a lesser extent than users, which will have existence as well as direct use values. Therefore, each mechanism can be perceived as not fair by different population groups.

\footnotetext{
${ }^{10}$ Existence values have been defined to include bequest, intrinsic, cognitive and altruistic values.
} 
In this study both, 'increased taxation' and 'user fees' received support by about 39\% of respondents which suggests that the average respondent is indifferent about which one is adopted $^{11}$. As expected regular visitors were less likely to support user fees as compared to nonvisitors, and high-income respondents were more supportive of user fees, as compared with lowincome respondents (See Table 6a). Taxes were equally supported by all income groups, but much more so by the visitors of public lands. This leads to the conclusion that there is no overwhelming reason to recommend fees over taxation since (a) both had the same degree of average support and (b) each has an adverse impact on the users or on the non-users of public lands, respectively. However, the additional burden that fees cause on low-income families is absent in the case of taxation. Given that equal access may be considered as a more important objective compared to efficiency, governments may want to consider tax increases rather than fees if they wish to raise the current level of funding.

\section{(ii) Other MP}

Among all MP that were considered, the 'adopt-a-site' policy, which would allow volunteer and citizen organizations to manage sites, received the greatest support (81\%) followed by donation boxes $(61.1 \%)$. Corporate sponsorship received support by the majority of respondents for two types of recreation facilities only: education facilities $(61.1 \%)$ and visitor centers $(61.8 \%)$.

Individual socio-economic characteristics and frequency of visitation were not associated with support for donation boxes or for 'adopt-a-site'. High-income respondents and non-visitors were more likely to support corporate sponsorship of visitor centers and education facilities.

As noted, opinions about corporate sponsorships differed significantly by types of recreation areas. Corporate sponsorships for visitor centers and education facilities were

\footnotetext{
${ }^{11}$ These findings are consistent with Bowker et al. (1999) who compared user fees, taxation, and combination of both, but did not find a dominating support for user fees only as opposed to taxation only.
} 
supported by the majority of respondents, followed by corporate sponsorships for campgrounds, supported by $45.9 \%$. Corporate sponsorships for the remaining categories faced grater opposition than support. These results suggest that corporate sponsorships need to be considered conservatively, and may not be welcome in many types of recreation areas. These results also suggest that the public may be concerned with both the type of MP and with the type of recreation site or facility that will be affected by management practices in general.

\section{Summary}

If policy makers use public acceptance as the decision criterion of recreation land management, a mixed policy consisting of the three management policies; donations, adopt-a-site and corporate sponsorships (for selected areas), may be the best way to raise revenues and maintain the nonexclusiveness of public recreation lands. A practice allowing for volunteer management and corporate sponsorships of education faculties and visitor centers may reduce the cost of maintenance which, complemented with donations to raise revenue may, at least in principle, secure sufficient funds, and will be accepted by the majority of the public.

The advantages of such mixed policy as compared to user fees or taxation are several. First, it would maintain the equal access for all subgroups of the population thus retaining the traditional status and purpose of public recreation lands. The insignificant effect of income and frequency of visitation implies that donation boxes and adopt-a-site practices would not affect low-income families, as would user fees, and would not be unfair to non-visitors of public lands as will be the case with increased taxation. Second, each of the proposed policies involves less governmental intervention, which has promise for greater efficiency. Donation boxes would raise 
direct revenues that could be spent on the site, and adopt-a-site and corporate sponsorships would reduce the cost for maintenance personnel that would be needed if user fees or taxation were used.

However, future research into whether such mixed form of management could raise enough revenues in practice is needed. Evidence suggests that donations have raised only limited amount of funds. Acadia National Park, for example was able to raise only $4 \%$ of the total revenues in 2003 through donations, while the remaining funds were colleted through fees (25\%) and governmental funds (55\%). In addition, there may not be enough volunteer groups to adopt all underfunded sites. Regulation and advertising of corporate sponsorships and adopt-asite offers would be another concern for policy makers. Finally, although corporate sponsorship of education facilities and visitor centers was accepted by the majority of respondents, if implemented in practice, this may result in more commercialization, and greater involvement of the private sector than initially envisioned ${ }^{12}$. Finally, policy makers who adopt donations, adopta-site and corporate sponsorships, may still need to use taxes or fees as a supplement. In relation to the comparative analysis earlier, we feel that the greatest share should be raised by taxation because this avoids the negative impact on low-income families associated with user fees.

\footnotetext{
${ }^{12}$ For a review of some principal issues that need to be considered in corporate sponsorships, see Mowen and Everett (2000).
} 
Table 1. Descriptive Statistics*, $\mathrm{n}=\mathbf{8 0 5}$

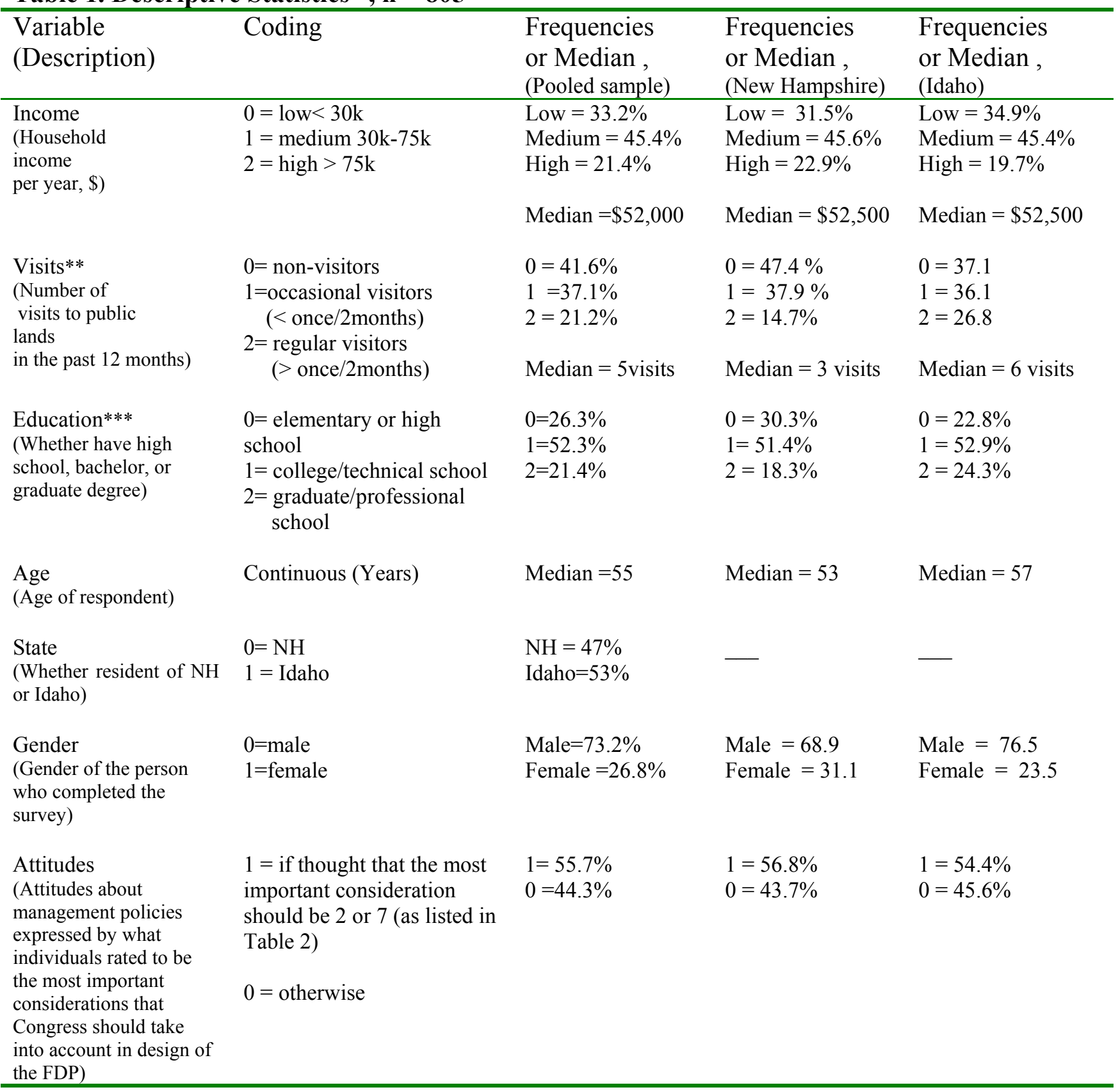

* US Census Bureau (2002) population statistics are as follows:

Median income $\quad \mathrm{NH}=\$ 53,549$. Idaho $=\$ 38,613$.

Education $\quad$ NH: $42 \%$ Elementary/high school, $47 \%$ College/technical school; $11 \%$ Graduate school; Idaho: 44\% Elementary/high School, 49\% College/technical School; 7\% Graduate school;

Median age $\quad \mathrm{NH}=38.2$ years; Idaho $=33.8$ years.

** Differences between states statistically significant at the $99 \%$ level.

*** Differences between states statistically significant at the $95 \%$ level. 
Table 2. Most important concerns that should be considered by Congress in evaluating the Fee Demonstration Program

Concern

Number of
respondents who
selected this
category*
$\mathrm{n}=765$
$(\%$ of total $)$

Proportion of respondents

who think it should be the

most important

consideration**

$\%$

1. Raising prices to make parks and recreation areas 200

11.2

pay for themselves so that repairs and improvements

can be made without tax dollars

2. Keeping public lands affordable for lower income

4. Reducing legislative oversight (because the fee activities

Other 
Table 3. Public response to FDP user fees*

\begin{tabular}{|c|c|c|c|c|}
\hline $\begin{array}{l}\text { Response (past } 12 \text { months) } \\
\mathrm{n}=794\end{array}$ & & $\begin{array}{l}\mathrm{N}(\%) \\
\text { (Pooled) }\end{array}$ & NH & Idaho \\
\hline $\begin{array}{l}\text { Have not visited public lands } \\
\text { in the past } 12 \text { months }\end{array}$ & & $\begin{array}{l}313 \\
(39.4)\end{array}$ & $\begin{array}{l}170 \\
(45.3)\end{array}$ & $\begin{array}{l}(142) \\
33.7)\end{array}$ \\
\hline \multirow[t]{4}{*}{$\begin{array}{l}\text { Have visited public lands } \\
\text { in the past } 12 \text { months }\end{array}$} & My visits were about the same & $\begin{array}{l}200 \\
(25.2)\end{array}$ & $\begin{array}{l}85 \\
(22.7)\end{array}$ & $\begin{array}{l}114 \\
(27.1)\end{array}$ \\
\hline & $\begin{array}{l}\text { Took fewer trips to public recreation } \\
\text { lands that have fees, or tried to use } \\
\text { sites that do not have entrance, access, } \\
\text { or parking fees, or avoided paying fees } \\
\text { by parking in nearby areas. }\end{array}$ & $\begin{array}{l}210 \\
(26.4)\end{array}$ & $\begin{array}{l}91 \\
(24.3)\end{array}$ & $\begin{array}{l}114 \\
(27.1)\end{array}$ \\
\hline & Other & $\begin{array}{l}71 \\
(9.0)\end{array}$ & $\begin{array}{l}29 \\
(7.7)\end{array}$ & $\begin{array}{l}51 \\
(12.1)\end{array}$ \\
\hline & & $100 \%$ & $100 \%$ & $100 \%$ \\
\hline \multirow[t]{2}{*}{$\begin{array}{l}\text { Among visitors } \\
\text { in the past } 12 \text { months }\end{array}$} & Paid a fee (at least one time) & $\begin{array}{l}315 \\
(39.6)\end{array}$ & $\begin{array}{l}128 \\
(34.1)\end{array}$ & $\begin{array}{l}182 \\
(43.2)\end{array}$ \\
\hline & Bought a pass & $\begin{array}{l}79 \\
(9.9)\end{array}$ & $\begin{array}{l}22 \\
(6.6)\end{array}$ & $\begin{array}{l}57 \\
(13.5)\end{array}$ \\
\hline
\end{tabular}

* Differences between states were statistically insignificant, except for number of respondents who bought a pass where the difference is significant at the $99 \%$ level. 
Table 4. Support for alternative management policies*, \%

\begin{tabular}{|c|c|c|c|}
\hline & Oppose & Support & $\begin{array}{l}\text { Not } \\
\text { Sure }\end{array}$ \\
\hline Put donation boxes in Forest Service parking lots & 20.1 & 61.1 & 18.8 \\
\hline $\begin{array}{l}\text { Require a fee of }(\$ 3, \$ 5 \text { or } \$ 10) \text { per site for } \\
\text { entrance to all areas }\end{array}$ & 49.5 & 39.1 & 11.4 \\
\hline Keep all areas free but reduce maintenance & 62.9 & 22.5 & 14.6 \\
\hline $\begin{array}{l}\text { Allow qualified volunteer and citizen } \\
\text { organizations to manage sites (adopt-a-site) }\end{array}$ & 6.3 & 81.0 & 12.7 \\
\hline Sell some of the areas to private companies & 84.3 & 6.6 & 9.1 \\
\hline Close areas that cost the most to maintain & 79.2 & 6.8 & 14.0 \\
\hline $\begin{array}{l}\text { Contract with private companies to manage the } \\
\text { areas }\end{array}$ & 48.7 & 28.8 & 22.5 \\
\hline $\begin{array}{l}\text { Keep sites free but increase federal income tax to } \\
\text { provide adequate funding. }\end{array}$ & 48.9 & 39.4 & 11.7 \\
\hline
\end{tabular}


Table 5. Break down of support for corporate sponsorship*, \%

\begin{tabular}{llcc}
\hline CORPORATE SPONSORSHIP & Support & Oppose & Not Sure \\
\hline Visitor centers & 61.8 & 23.5 & 14.6 \\
Hiking trails & 37.7 & 44.3 & 17.9 \\
Campgrounds & 45.9 & 35.9 & 18.0 \\
Scenic overlooks & 37.3 & 46.0 & 16.7 \\
Education facilities & 61.1 & 23.0 & 15.9 \\
Nature walks & 36.7 & 44.2 & 19.1 \\
Cross-country ski trails & 39.0 & 42.7 & 18.5 \\
$\begin{array}{l}\text { Snowmobile trails } \\
\text { Horse trails }\end{array}$ & 39.6 & 41.4 & 18.0 \\
$\begin{array}{l}\text { Nationally significant trails such as } \\
\text { the Appalachian or Pacific Crest Trails }\end{array}$ & 39.1 & 42.0 & 18.9 \\
$\begin{array}{l}\text { Average support of corporate sponsorships } \\
\text { * Percentage of support was statistically indistinguishable between states (using a chi-square test for equal } \\
\text { proportions) except for support for nationally significant trails. }\end{array}$ & 34.7 & 45.6 & 19.6 \\
\hline
\end{tabular}


Table 6a. Regression results for support for each MP

Coefficient estimates (St. errors) and 95\% Odds ratios

\begin{tabular}{|c|c|c|c|c|c|c|c|c|}
\hline Variable & $\begin{array}{l}\text { Donation } \\
\text { Boxes }\end{array}$ & $\begin{array}{l}\text { User } \\
\text { fees }\end{array}$ & $\begin{array}{l}\text { Reduced } \\
\text { Maintenance }\end{array}$ & Adopt-a-site & $\begin{array}{l}\text { Sell some } \\
\text { areas }\end{array}$ & $\begin{array}{l}\text { Close areas } \\
\text { that cost most } \\
\text { to maintain }\end{array}$ & $\begin{array}{l}\text { Contract with } \\
\text { private companies } \\
\text { to manage sites }\end{array}$ & $\begin{array}{l}\text { Increased } \\
\text { taxation }\end{array}$ \\
\hline Intercept & $2.52(0.7) * * *$ & $-0.95(0.58)$ & $-1.7(0.65)$ & $2.64(1.20)^{* *}$ & $-2.12(1.09)^{*}$ & $-2.69(1.11) * *$ & $-0.88(0.61)$ & $-2.28(0.59)$ \\
\hline Income & $\begin{array}{l}-0.17(0.18) \\
0.6-1.2\end{array}$ & $\begin{array}{l}0.38(0.15)^{* * *} \\
1.1-1.9\end{array}$ & $\begin{array}{l}0.03(0.15) \\
0.7-1.4\end{array}$ & $\begin{array}{l}0.45(0.29) \\
0.9-2.8\end{array}$ & $\begin{array}{l}0.21(0.26) \\
0.7-2.1\end{array}$ & $\begin{array}{l}0.14(0.25) \\
0.7-1.9\end{array}$ & $\begin{array}{l}0.43(0.15) * * * \\
1.1-2.1\end{array}$ & $\begin{array}{l}0.14(0.14) \\
0.9-1.5\end{array}$ \\
\hline Visits & $\begin{array}{l}0.04(0.16) \\
0.7-1.4\end{array}$ & $\begin{array}{l}-0.69(0.13) * * * \\
0.4-0.6\end{array}$ & $\begin{array}{l}0.51(0.14)^{* * *} \\
1.3-2.2\end{array}$ & $\begin{array}{l}0.08(0.26) \\
0.6-1.8\end{array}$ & $\begin{array}{l}-0.58(0.24)^{* *} \\
0.3-0.9\end{array}$ & $\begin{array}{l}-0.26(0.24) \\
0.5-1.2\end{array}$ & $\begin{array}{l}-0.27(0.13) \text { ** } \\
0.6-0.9\end{array}$ & $\begin{array}{l}0.35(0.13) * * * \\
1.1-1.8\end{array}$ \\
\hline Education & $\begin{array}{l}0.09(0.18) \\
0.8-1.6\end{array}$ & $\begin{array}{l}-0.16(0.14) \\
0.6-1.1\end{array}$ & $\begin{array}{l}-0.15(0.16) \\
0.6-1.2\end{array}$ & $\begin{array}{l}-0.05(0.29) \\
0.5-1.7\end{array}$ & $\begin{array}{l}0.63(0.27)^{* *} \\
1.1-3.2\end{array}$ & $\begin{array}{l}0.16(0.27) \\
0.7-1.9\end{array}$ & $\begin{array}{l}0.19(0.15) \\
0.9-1.6\end{array}$ & $\begin{array}{l}0.27(0.15) * \\
1.0-1.7\end{array}$ \\
\hline Age & $\begin{array}{l}-0.32(0.08)^{* * *} \\
0.6-0.8\end{array}$ & $\begin{array}{l}0.17(0.06)^{* *} \\
1.0-1.4\end{array}$ & $\begin{array}{l}0.03(0.07) \\
0.9-1.2\end{array}$ & $\begin{array}{l}-0.21(0.14) \\
0.6-1.1\end{array}$ & $\begin{array}{l}-0.04(0.13) \\
0.7-1.2\end{array}$ & $\begin{array}{l}0.06(0.13) \\
0.8-1.4\end{array}$ & $\begin{array}{l}-0.05(0.07) \\
0.8-1.1\end{array}$ & $\begin{array}{l}0.02(0.06) \\
0.9-1.2\end{array}$ \\
\hline State & $\begin{array}{l}0.20(0.23) \\
0.7-1.9\end{array}$ & $\begin{array}{l}-0.02(0.18) \\
0.7-1.4\end{array}$ & $\begin{array}{l}0.16(0.21) \\
0.8-1.8\end{array}$ & $\begin{array}{l}-0.21(0.38) \\
0.4-1.7\end{array}$ & $\begin{array}{l}0.01(0.33) \\
0.5-1.9\end{array}$ & $\begin{array}{l}0.82(0.38)^{* *} \\
1.1-4.8\end{array}$ & $\begin{array}{l}0.23(0.20) \\
0.8-1.9\end{array}$ & $\begin{array}{l}0.31(0.18) * \\
0.9-1.9\end{array}$ \\
\hline Gender & $\begin{array}{l}-0.20(0.26) \\
0.5-1.4\end{array}$ & $\begin{array}{l}0.30(0.21) \\
0.9-2.1\end{array}$ & $\begin{array}{l}-0.16(0.24) \\
0.5-1.4\end{array}$ & $\begin{array}{l}0.11(0.42) \\
0.5-2.6\end{array}$ & $\begin{array}{l}-0.62(0.45) \\
0.2-1.3\end{array}$ & $\begin{array}{l}-0.37(0.45) \\
0.3-1.6\end{array}$ & $\begin{array}{l}-0.22(0.23) \\
0.5-1.3\end{array}$ & $\begin{array}{l}0.31(0.21) \\
0.9-2.1\end{array}$ \\
\hline Attitudes & $\begin{array}{l}0.64(0.22) * * * \\
1.2-3.0\end{array}$ & $\begin{array}{l}-0.54(0.18) * * * \\
0.4-0.8\end{array}$ & $\begin{array}{l}0.45(0.21)^{* *} \\
1.0-2.4\end{array}$ & $\begin{array}{l}0.20(0.37) \\
0.6-2.5\end{array}$ & $\begin{array}{l}-0.47(0.34) \\
0.3-1.2\end{array}$ & $\begin{array}{l}-0.72(0.35)^{* *} \\
0.2-0.9\end{array}$ & $\begin{array}{l}-0.14(0.19) \\
0.6-1.3\end{array}$ & $\begin{array}{l}0.98(0.19) * * * \\
1.9-3.9\end{array}$ \\
\hline $\begin{array}{l}\text { LR } \\
n\end{array}$ & $\begin{array}{l}<0.001 \\
479\end{array}$ & $\begin{array}{l}<0.001 \\
542\end{array}$ & $\begin{array}{l}0.005 \\
518\end{array}$ & $\begin{array}{l}0.27 \\
544\end{array}$ & $\begin{array}{l}0.02 \\
564\end{array}$ & $\begin{array}{l}0.05 \\
523\end{array}$ & $\begin{array}{l}0.006 \\
478\end{array}$ & $\begin{array}{l}<0.001 \\
552\end{array}$ \\
\hline
\end{tabular}

$* * *$ Significant at $99 \%$ level

** Significant at $95 \%$ level

* Significant at $90 \%$ level 
Table 6b. Regression results for support for corporate sponsorships

Coefficient estimates (St. errors) and 95\% Odds ratios

\begin{tabular}{|c|c|c|c|c|c|}
\hline Variable & $\begin{array}{l}\text { Visitor Centers } \\
\text { and education } \\
\text { facilities }\end{array}$ & $\begin{array}{l}\text { Scenic } \\
\text { Overlooks and } \\
\text { Nature walks }\end{array}$ & $\begin{array}{l}\text { Hiking, skiing, } \\
\text { snowmobile } \\
\text { and horse } \\
\text { trails }\end{array}$ & $\begin{array}{l}\text { Camp } \\
\text { grounds }\end{array}$ & $\begin{array}{l}\text { Nationally } \\
\text { significant trails, } \\
\text { such as the } \\
\text { Appalachian, etc. }\end{array}$ \\
\hline Intercept & $0.45(0.64)$ & $-0.76(0.61)$ & $-0.31(0.61)$ & $0.01(0.57)$ & $-0.97(0.58)$ \\
\hline Income & $\begin{array}{l}0.25(0.15)^{*} \\
1.0-1.7\end{array}$ & $\begin{array}{l}0.11(0.15) \\
0.8-1.5\end{array}$ & $\begin{array}{l}0.10(0.14) \\
0.8-1.5\end{array}$ & $\begin{array}{l}0.24(0.13)^{*} \\
1.0-1.6\end{array}$ & $\begin{array}{l}0.13(0.14) \\
0.9-1.5\end{array}$ \\
\hline Visits & $\begin{array}{l}-0.28(0.14)^{* *} \\
0.6-1.0\end{array}$ & $\begin{array}{l}-0.43(0.14)^{* * *} \\
0.5-0.8\end{array}$ & $\begin{array}{l}-0.43(0.14)^{* * *} \\
0.5-0.8\end{array}$ & $\begin{array}{l}-0.26(0.12)^{* *} \\
0.6-0.9\end{array}$ & $\begin{array}{l}-0.32(0.13)^{* *} \\
0.5-0.9\end{array}$ \\
\hline Education & $\begin{array}{l}-0.08(0.15) \\
0.7-1.2\end{array}$ & $\begin{array}{l}0.07(0.15) \\
0.8-1.5\end{array}$ & $\begin{array}{l}0.18(0.15) \\
0.9-1.6\end{array}$ & $\begin{array}{l}0.03(0.14) \\
0.7-1.3\end{array}$ & $\begin{array}{l}-0.13(0.14) \\
0.6-1.2\end{array}$ \\
\hline Age & $\begin{array}{l}-0.05(0.07) \\
0.8-1.1\end{array}$ & $0.03(0.07)$ & $\begin{array}{l}-0.03(0.07) \\
0.8-1.1\end{array}$ & $\begin{array}{l}0.02(0.06) \\
0.9-1.2\end{array}$ & $\begin{array}{l}0.13(0.07)^{*} \\
1.0-1.3\end{array}$ \\
\hline State & $\begin{array}{l}0.17(0.20) \\
0.8-1.8\end{array}$ & $\begin{array}{l}0.48(0.20)^{* *} \\
1.1-2.4\end{array}$ & $\begin{array}{l}0.30(0.20) \\
0.9-2.0\end{array}$ & $\begin{array}{l}0.001(0.18) \\
0.7-1.4\end{array}$ & $\begin{array}{l}0.48(0.18)^{* *} \\
1.1-2.3\end{array}$ \\
\hline Gender & $\begin{array}{l}0.09(0.24) \\
0.7-1.8\end{array}$ & $\begin{array}{l}-0.16(0.23) \\
0.5-1.3\end{array}$ & $\begin{array}{l}-0.12(0.23) \\
0.6-1.4\end{array}$ & $\begin{array}{l}-0.23(0.21) \\
0.5-1.2\end{array}$ & $\begin{array}{l}-0.13(0.22) \\
0.6-1.3\end{array}$ \\
\hline Attitudes & $\begin{array}{l}0.40(0.20)^{* *} \\
1.0-2.2\end{array}$ & $\begin{array}{l}0.27(0.20) \\
0.9-1.9\end{array}$ & $\begin{array}{l}0.07(0.20) \\
0.7-1.5\end{array}$ & $\begin{array}{l}0.25(0.18) \\
0.9-1.8\end{array}$ & $\begin{array}{l}0.37(0.18)^{* *} \\
1.0-2.1\end{array}$ \\
\hline $\begin{array}{l}\text { LR } \\
\mathrm{n}\end{array}$ & $\begin{array}{l}0.09 \\
505\end{array}$ & $\begin{array}{l}0.01 \\
484\end{array}$ & $\begin{array}{l}0.09 \\
466\end{array}$ & $\begin{array}{l}0.15 \\
515\end{array}$ & $\begin{array}{l}<0.001 \\
511\end{array}$ \\
\hline
\end{tabular}




\section{References}

Acadia National Park (2003). Acadia National Park Business Plan. Cited in:

http://www.nps.gov/acad/management.htm

Alberini, A., Boyle, K. and Welsh, M. (2003). Analysis of Contingent Valuation Data With Multiple Bids and Response Options Allowing Respondents to Express Uncertainty. Journal of Environmental Economics and Management. 45, 40-62.

Bowker, J.M., Cordell, H.K., Johnson, C.Y. (1999). User Fees for Recreation Services on Public Lands: A National Assessment. Journal of Park and Recreation Administration, 17(3):1-14.

Carson, R.T., Hanemann, M.W. Kopp, R.J., Krosnick, J.A., Mithcell, R.C., Presser, S., Ruud, P.A., Smith, K.V. (1998). Referendum Design and Contingent Valuation: The NOAA Panel's No-Vote Recommendation. Review of Economics and Statistics, 80(3), 484-87.

Dillman, D. A. (2001). Mail and Internet Surveys. “The Tailored Design Method". New York: John Wiley \& Sons, Inc.

Giraud K.L. (2001). Demand Analysis and Visitor Preferences for the Chena River Recreation Area, Alaska. Journal of Park and Recreation Administration, 19(2):98-112.

More, T. (1999). A Functionalist Approach to User Fees Journal of Leisure Research. 31(3):22744.

More, T., Stevens, T. (2000). Do User Fees Exclude Low-income People from Resource-based Recreation? Journal of Leisure Research, 32(3): 341-57.

Mowen, A.J., Graefe, A.R. (2002). Public Attitudes Toward the Corporate Sponsorship of Park Agencies: The Role of Promotional Activities and Contractual Conditions. Journal of Park and Recreation Administration, 20(2): 31-48.

Mowen, A.J., Everett, P.B. (2000). Six Questions to Ask When Screening Corporate Partners. Journal of Park and Recreation Administration, 18(4): 1-16.

Mowen, A.J., Frankeberger, S. (2000). Public Preferences for Park and Recreation Sponsorships. Leisure/Loisir, 24(3-4):187-205.

Richer ,J.R., Christensen,N.A. Appropriate Fees for Wilderness Day Use: Pricing Decisions for Recreation on Public Land. Journal of Leisure Research. 31. No 3, 269-280 (1999).

Schneider,I.E., Budruk,M. Displacement as a Response to the Federal Recreation Fee Program. Journal of Park and Recreation Administration. 17,3,76-84. (1999).

Solop, F.I., Hagen, K.K., Ostergren, D. (2003). National Park Service Fees: An Examination of Public Attitudes Technical Report. Social Research Laboratory, Northern Arizona University. 
US Census Bureau. (2002). American Community Survey Profile Cited in:

http://www.census.gov/acs/www/Products/Profiles/Single/2002/ACS/Narrative/040/NP04000US16.htm.

Vogt, C.A. Williams, D.R. (1999). Support for Wilderness Recreation Fees: The Influence of Fee Purpose and Day versus Overnight Use. Journal of Park Recreation and administration. 17,3,8599.

Wang, H. (1997). Treatment of Don't Know Responses in Contingent Valuation Surveys: A Random Valuation Model. Journal of Environmental Economics and Management. 32(2): 21932 .

Williams, D.R., Vogt,C.A., Vitterso,J. (1999). Structural Equation Modelling of Users' Response to Wilderness Recreation Fees. Journal of Leisure Research. 31,3,245-268.

Winter, P.L., Palucki,L.J., Burkhard,R.L. (1999). Anticipated Responses to a Fee Program: The Key is Trust. Journal of Leisure Research. 31,3,207-226. 